\title{
Effects of water quality of the Buguma creek on tilapia culture
}

\author{
Edun, O. M. / Alon, R. / Panpinit, P. / Dokubo, T. / Nweke, F. / Ogolo, C.
}

\section{Abstract}

Ecological parameters of water samples of the Buyuma creek were evaluated. The parameters varied between high and low tide, with the maximum salinity level of $20 \%$ and lowest level $9 \%$ The highest $p H$ value of 7.7 occurred in Jamuary and lowest 5 in May. Similarly, maximum ammonia level of $2 \mathrm{mg} / \mathrm{l}$ was observed in May and consistently low levels $(<0.5 \mathrm{mg} /$ ) in the other months. We cliscuss the viability of Litapia aquaculture and suitability of Buguma creek for its culture.

Keywords: Tilapia, Aquaculture, brackish water, water quality.

\section{Introduction}

quaculture in Nigeria is yet to reach its potential. The relative advantages in the country with tropical climate and
almost unlimited water supply are not enough, while pollution and resources are limiting and restricting the develop-
ment of this sector. Water quality is the first most important limiting factor in pond fish culture. Water quality deter-
mines to a great extent the success or failure of a fish culture operation (Piper et al., 1982). A good understanding of the water
movement and mixing patterns as well as temporal and spatial variability of the physical and chemical characteristics of the
river are important when selecting potential aquaculture species for commercial production (Joyce et al., 2010).

Aquaculture has a major advantage over the decreasing capture fisheries as the time of harvest can be synchronized to coincide with market demand (FAO, 2008).Nigeria has large areas of highly productive inland waters (Ita, 1993). There is considerable potential for aquaculturc in the Niger Delta region. Despite this great potential, brackish water aquaculture contributes very little to fish production in Nigeria (Dublin-Green et al., 2003).

Buguma creek has a history of aquaculture but only at experimental or pilot scales. The underutilization of this mangrove swamps is mainly due to problems associated with the acidic nature of the soils and management (Dublin-Green and Ojanuga, 1988). The soil acidifies the overlying pond water rapidly. Shimang (1999) ascribed the underutilization to lack of knowledge on the profitability of aquaculture as a commercial enterprise and lack of fish farm management techniques. However the success of small aquaculture trials has raised interest in the establishment of commercial tilapia farm. The demand for tilapia in the Niger Delta region largely outstrips supply to the extent that fish of very small size are sold in the market. Management of the Buguma creek for culture of tilapia have received little attention. The objective of this study is to identify the critical limiting factors in the Buguma creek for effective management of tilapia culture.

\section{Materials and Methods}

Description of the study area: The New Calabar River lies on the eastern arm of the Niger Delta and empties into some creeks and coastal lagoons bordering the Atlantic Ocean (RPI, 1985). Buguma creek is downstream where the water is brackish and tidal with intertidal flats influenced by scmi-diurnal tidal regime. The climatc of the area is characterized by dry season during November to March and rainy season from April to October. The mean annual rainfall is about 2,025 mm. Red mangrove (Rhizophora sp.), White mangrove (Avicenia sp.) and Nypa palm (Nypa fructicans) dominates the vegetation.

Evaluation of water quality parameters: Water samples were collected twice daily from the River and monitored for Ammonia, $\mathrm{pH}$ and Salinity values. The water quality parameters were monitored at high and low tides from January to July, 2013. The salinity of the water was measured with a hand refractometer (Vitalsine Model SR-6). The $\mathrm{pH}$ value of the water was measured in situ by immersing a digital $\mathrm{pH}$ meter (IIANNA Instruments, Woonsocket, USA) which had been calibrated with buffer solutions of $\mathrm{pH} 4$ and 7. The ammonia levels of the surface waters were measured by using Aquamerck test kit 
(Merck, Damstadt, Germany).

\section{Results}

- Salinity: Variations in salinity levels are shown in Figure 1. The highest salinity level was observed in March and May while the lowest level was observed in January and Junc.

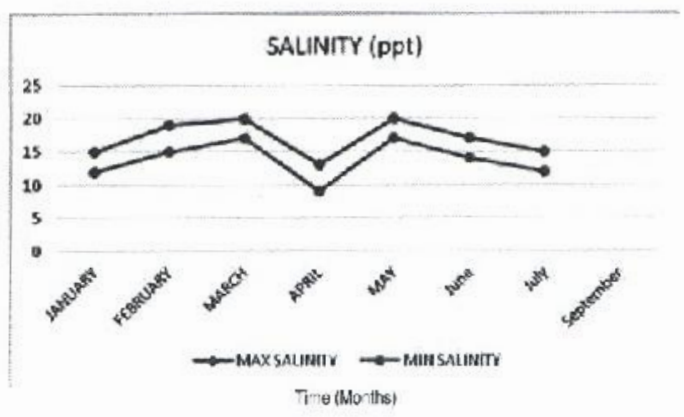

Fig. 1: Maximum and minimum levels of salinity over time.

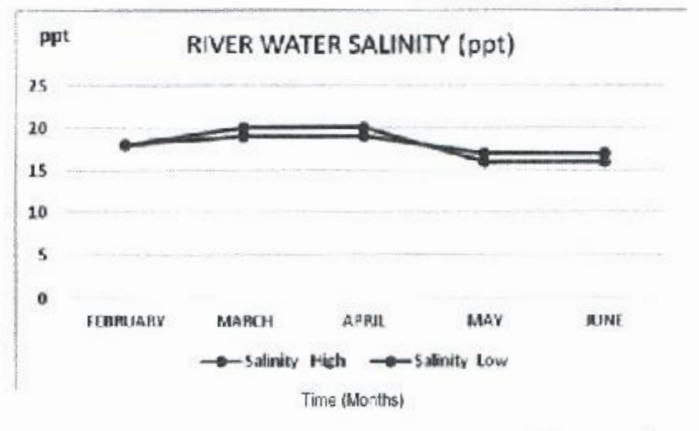

Fig. 2: Variations in salinity during high and low tides over time.

- pH: The maximum and minimum levels of pH overtime are presented in Fig. 3 while the variations from the different months are shown in Fig. 4. The values ranged from 6.6 to 7.7, with the exceptionally low (5.0) occurring in May.

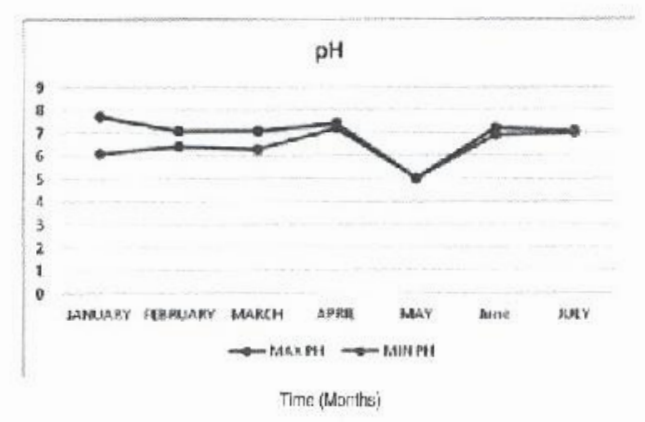

Fig. 3: Minimum and maximum levels of $\mathrm{pH}$ over time.

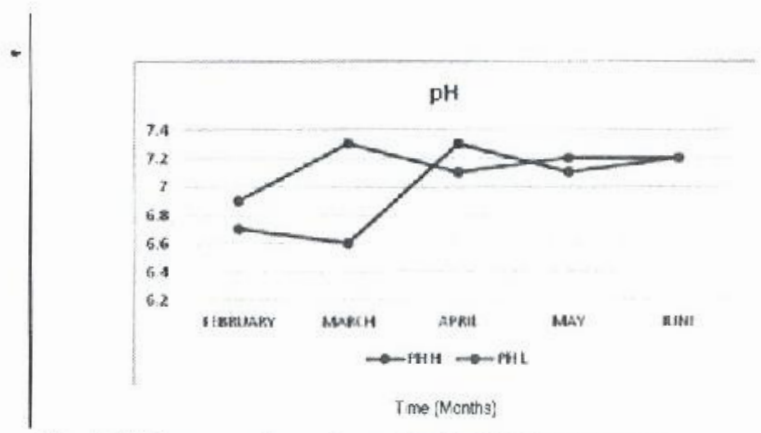

Fig. 4: Minimum and maximum levels of $\mathrm{pH}$ during high and low tides.

- Ammonia: The levels of ammonia from the Buguma creek are shown in Figure 5.The maximum $(2 \mathrm{mg} / 1)$ occurred in May. In contrast, the levels of ammonia were consistently low in the other months $(<0.5 \mathrm{mg} / 1)$.

\section{Discussion}

The daily tides do not have significant effects on the river water salinities at the fish farm location. The brackish water is considered stable and no daily changes are evident. This enables Tilapia fish to minimize energy consumption due to osmoregulation. This is favourable and suitable for the cultivation of tilapia since the fish homeostatic system is continuously affected by the changes of the level of salinity (Imslaad et al., 2008). The reduction in salinity in April may be as a result of heavy rain fall and fresh water runoff to the river with organic matter. This is consistent with the findings of Edun and F.fuvwcrwere (2012), Deekae et al. (2010), Abowei and George (2009) and Owhonda et al. (2007).

Reduction in $\mathrm{pH}$ during April-May as indicated in Figure 3 correlates to the lower salinity during this time of the year as a result of the rain. Acid rain may be one of the reasons and another is the decomposition of organic matter washed into the river. Regular monitoring of the $\mathrm{pH}$ should be carried out, the acidification of pond water usually experienced in this swamp causes poor fertilization response, low pond productivity, slow fish growth, fish mortalities and low fish yields (Dublin-Green et al., 2003).Control of $\mathrm{pH}$ is essential for minimizing ammonia and hydrogen sulphide toxicity. Nevertheless, $\mathrm{pH}$ was relatively stable throughout the period of investigation and fa. vours Tilapia fish culture.

Figure 5 shows very low ammonia levels (near zero most of the time) ex-

Fig. 5: Minimum and maximum ammonia levels over time. cept in May when we recorded relatively higher values of $2 \mathrm{mg} / \mathrm{l}$. It is extremely important to monitor ammonia levels frequently. Control of $\mathrm{pH}$ is essential for minimizing ammonia and hydrogen sulphide toxicity. Dublin-Green (2003) reported the effectiveness of tidal flushing in improving pond water quality and fish yield in brackish water earthen ponds to about $1.25 \mathrm{mt} / \mathrm{ha} / \mathrm{yr}$. The use of circular pond lined with polypropylene was found to be very effective for the culture of Tilapia in this study. Good production from the pond was achieved and this would increase the yield to $1000 \mathrm{mt} / \mathrm{yr}$. Pumping of water into the ponds was donc only at high tide. 
Most of the water quality problems were solved with continuous water exchange accompanied with running of paddle wheels, the use of air stones and injection of pure oxygen. The paddle wheel was employed to have the water fully mixed. Massive water replacement is not recommended, it is better to pump new water, have the paddle whecl running to homogenize water throughout the pond before discharging the water.

\section{Conclusion}

Fish farmers should be accustomed to monitoring the water quality parameters before introducing water from the Buguma creek into fish culture ponds. Development of aquaculture activities in this swamp should go beyond the facilities and quality of water but also on the aspects of water quality management. Interpretation of the parameters is also crucial to maintain healthy fish stock. The Buguma creek has many of the physical characteristics required for tilapia culture but a range of technology, constant electricity supply and good management must be put in place.

\section{REFERENCES}

Abowei, J.F.N. and A.D.I. George.(2009). Some physical and chemical in Okpoko Creek, Niger Delta, Nigeria. Research Journal of Environmental and Earth Sciences, 1(2):45-53.

Deekae, S.N., Abowei, J.F.N.and Alfred-Ockiya, J.F. (2010). Seasonal variation of some physical and chemical parameters of Luubara Creek, Niger Delta, Nigeria. Research Journal of Environmental and Eurth Sciences, 2(4): 208-215.

Dublin-Green, C.O., Ayinla, O.A. and Ogori, K.T. (2003). Management of fish ponds built on acid sulphate soils in Buguma creek, Niger Delta, Nigeria. Journal of Applied Sciences and Environmental Managcment, 7(2):39-43.

Dublin-Green, C.O. and Ojanuga, A.G. (1988).The problem of acid-sulphate soils in brackish water aquaculture.NIOMR Technical Paper 45:1-20.

Edun, O.M and Efiuvwevwere, B.J.O. (2012). Bacterial profiles and physico-chemical parameters of water samples from different siles of New Calabar River, Nigeria. Sustuinable Agricuiture Restarch, 1(2):162-169.

Food and Agriculture Organization (FAO) 2008.Coastal Aquaculture: development perspectives in Africa and case studies. FAO Corporate Document Repository.

Imslaad, A.K., Gustaisson, A., Gunnarsson, S., Fossa, A., Amason, J., Amason, I.,.Jonsion, A.F., Sinradottis, H. and Thorarensen, H. (2008). Effects of reduced salinitics on growth, feed conversion efficiency and blood physiology of juvenile Atlantic halibul (Hippoglossus hippoglosus). Aquaculture, 2:254-259.

Ita, E.O. (1993). Inland Fisheries Resources of Nigeria. CIFA Occasional Paper No.2.Rome: FAO

Joyce, A.M., Rubio - Zuazo and Winberg, P.C. (2010). Environunental and Socio-Economie Considerations for Aquaculture in Jervis Bay, NSW. Canberra: Fisheries Research and Development Corporation. Project No.2009/328.11

Owhonda,N.K.,,Akinrotimi, O.A., Ansa, E.J., Edun, O.M., Anyanwu, P.E., Opara, J.Y. and Onunkwo, D.O. (2007). Wet season variation in some physicochemical parameters of brackishwater fish ponds and main channels in Buguma, Rivers State, Nigeria. Journal of Fisheries International, 2(3): $255-259$.

Piper, R.G., McElwain, I.B., Orme, L.E., MeCraren, J.P., Flower, L.G. and Leonard, J.R. (1982). Fish hatchery management. U.S. Fish and Wildlife Service, Washington.

Research Planning Institute (RPI) (1985). Environmental baseline studies for the establishment of control criteria and standards against petroleum related pollution in Nigeria. Research Planning Insitite Inc.Colombia, USA. Report No.RPL/R/84/4/1507

Shimang, G.N. (1999). Status Review of aquaculture development in Nigeria (1940 - 1998), Ahuja, Nigeria: Federal Department of Fisheries. 